\title{
The Use of Wa'Dan in Islamic Contract FX Forward: Weighting between Maslahah and Mafsadah
}

\author{
Azlin Alisa Ahmad ${ }^{1}$, Salmy Edawati Yaacob ${ }^{1} \&$ Mat Noor Mat Zain $^{1}$ \\ ${ }^{1}$ Department of Syariah, Fakulty of Islamic Studies, The National University of Malaysia, Malaysia \\ Correspondence: Azlin Alisa Ahmad, Department of Syariah, Fakulty of Islamic Studies, The National \\ University of Malaysia, 43600 Bangi, Selangor, Malaysia. E-mail: azlinalisa@gmail.com
}

Received: June 19, 2014 Accepted: August 30, 2014 Online Published: October 30, 2014

doi:10.5539/ass.v10n22p332 URL: http://dx.doi.org/10.5539/ass.v10n22p332

\begin{abstract}
Islamic foreign exchange forward contract widely use the principle of wa'd in order to fulfil the need of hedging. The contract is an alternative solution to conventional forward contract, whereby one party will promise to the other party to exchange currency at an agreed rate for a future date. The adaptation of wa'd (unilateral promise) or wa'dan (two unilateral promise) is seen as an exit mechanism or makharij to the impermissible conventional derivatives contract. Some opined that it is merely mimicking conventional products and labelling them as 'Islamic' in form alone. As a subsequence, it gives the same effect as conventional derivative contract and would create some economic problems. Hence, the objective of this paper is to examine the Islamic foreign exchange forward contract based on wa'dan in shariah perspectives, whether it will attain maslahah or mafsadah to the people. This study took the form of a qualitative study using the approach of content analysis method as a research design. Documents analysed in this study are al-Quran and some related maxims of jurisprudence. This study found that Islamic foreign exchange forward contract give some maslahah to the parties involved, including investors, financial institutions, corporate sectors, and Islamic economy at large. This is due to the urgent need of the Islamic economy to the Islamic hedging to solve the problem of price volatility in the market. Nevertheless, the adaptation of wa'dan principle in the Islamic foreign exchange forward contract would also lead to mafsadah as it would threaten the economy if the contract is misused for merely speculation purposes.
\end{abstract}

Keywords: wa'd, wa'dan, Islamic FX forward

\section{Introduction}

Islam has outlined clear rules and regulations on every financial transactions carried out by market players. This means that they are forbidden to do any activity that is against shariah guidelines as shariah compliance is an integral feature in the Islamic finance. Since the basic shariah principle of muamalah says that all forms of muamalah are permissible, as long as there is no dalil that prohibits, thus we can develop any new contract as long as it does not against shariah.

As Islamic banks have to cater the clients' need, they must be innovative in structuring any products offered. Therefore, Islamic banks are allowed to structure Islamic derivative products that can provide the same effect as conventional derivatives, although the possibility of restructuring involves techniques such as makharij. The adaptation of wa'dan principle in Islamic forward foreign exchange contract is one of the means for Islamic banks to evolve into a sophisticated global business. Since the exploration of a new product is a form of ijtihad, then principle of wa'd which is sometimes seen as makhraj technique is allowed in Islam because its intended use is to achieve maqasid al-shari'ah. It is undeniable that the contract musamma (known and recognized contract) is the ideal solution to the situation and needs in the past and the present. However, the jurist also has to introduce some new contracts due to changes in time and need of people, as long as they do not conflict with shariah.

In conventional practice, the issue of riba (usury) arises in the foreign exchange forward contract when the parties involved will fix a rate on the day contract is concluded, but the exchange of currency will happen in the future. This activity clearly involve riba as it does not fulfill the rule of sarf contract, which is the exchange of two different currencies must be done on a spot basis. Based on the rule of sarf, hence wa'd principle is widely used in Islamic forward foreign exchange contract in Islamic banking current practice. This contract is structured to achieve the function of conventional foreign exchange contract without contravene the fundamental shariah 
prohibitions, which is the prohibition of riba. The contract is constructed mainly to fulfil the need of hedging and risk management.

Islam recognizes the concept of hedging with respect to managing risk as it could protect wealth of people. Hedging is basically permissible and recommend in Islam since it reduce risk that might harm business and economy (Alisa \& 'Afifi, 2014). It is also consistent with maqasid al-shari'ah which emphasizes on the preservation of wealth (hifz al-mal). The issue arises is, to what extent the Islamic foreign exchange forward which is structured for hedging can achieve maqasid al-shariah? Is this contract will promote maslahah or mafsadah to the economy?

Based on that issue, this study took the form of a qualitative study using the approach of content analysis method as a research design. Documents analysed in this study are al-Quran and some related maxims of jurisprudence. This study uses methods of textual analysis and analysing theory of maslahah for data analysis method. This study will be entirely literature-based as it adopts the methodology of theoretical analysis.

Therefore, this paper wills mainly discuss on the principle of wa'dan which is adopted in forward foreign exchange contract. As wa'dan is taken from the principle of $w a^{\prime} d$ (unilateral promise), then this paper will begin with a brief discussion on $w a ' d$, followed by a theory of maslahah and mafsadah. Then, the contract will be analysed based on their achievement of maqasid al-shari'ah and also a clash between maslahah and mafsadah.

\section{Concept of $W a^{\prime} d$}

$W a^{\prime} d$ means a promise that connotes an expression of willingness of a person to another group of people on a particular subject matter. According to al-Fayyumi (2008), wa'd means notification of goods or bad news, but the term $w a^{\prime} d$ is commonly used to notice good news. According to Nurdianawati (2008), wa'd in practical sense has no specific definition of its own. However, it can be explained as a commitment made by one person to another to undertake a certain action beneficial to the other party. In a commercial transaction, a promise carries dual meaning; an offer from the offered is known as promise, and acceptance from the offered is also recognizing as promise. Hence, the promise made is binding on the offers themselves and will become enforceable once the offered comes forward and fulfills the conditions and requirements made for the acceptance of such offers (Billah, 2003).

Many of the scholars believe that fulfilling promise is a noble quality and its breaching is reproachable in Islam. The status of promise in Islam is crucial because it is one of the characteristics of a true believer and a person who breaks his promise is considered as munafiq, "Four qualities denote the hypocrite: when he talks he lies; his promise he does not keep; his covenant he betrays; and when he argues he exceeds the limit" (Bukhari, Sahih Bukhari, kitab al-Iman). Moreover, Allah S.W.T has also repeated the word wa'd more than 150 times in al-Qur'an to show it significance (Daghi, 2002).

The Shariah Advisory Council of Bank Negara Malaysia had decided that Islamic financial institutions must execute their forward exchange transactions based on unilateral binding promise (wa'd mulzim) that binds the promisor in the contract, who is liable to pay damages if he breaches his promise. However, this transaction is only allowed for the purpose of hedging (Bank Negara Malaysia, 2010). The Shariah Standard AAOIFI also states that a wa'd mulzim that binds one party is allowed in foreign exchange transactions. However, muwa'adah that binds both parties is not allowed, even for the purpose of hedging (AAOIFI, 2010).

In light of the above, the concept of wa'dan may be directly understood from the construction of $w a^{c} d$, where it may be concluded that the term wa'dan refers to two promises made by the parties involved in a particular deal or business. These two promises are given unilaterally by one party to another and vice versa, whereby they are unrelated to each other and their respective fulfillment depends on two independent conditions (Aznan, 2008; Shamsiah \& Rusnah, 2010).The concept of wa dan may be illustrated as follows:

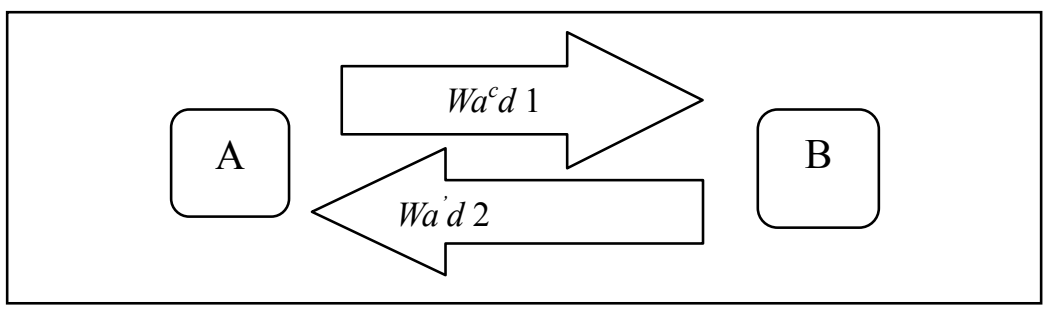

Figure 1. The Wa'dan process

Source: Aznan (2008) 
According to Shamsiah \& Rusnah (2010), the main conditions or requirements to qualify two promises made by two parties as a wa'dan are: (1) the two promises are unrelated to each other; and (2) the effect of both promises is different and independent of each other.

\section{Theory of Maslahah}

Shariah is built on universal human maslahah as Islam was revealed to preserve the benefit of the whole human and society. Islam give blessings to all human beings dan provide comprehensive solutions to any problems. The life and property of all people should be protected in Islam. Hence, all rules dan regulations set by God is meant to promote the benefit (maslahah) and give protection to entire human beings. As Islam is a religion of ease, thus making things easy and removing difficulties are among the foremost objectives of Islamic Law.

Allah Almighty says:

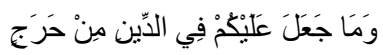

Meaning:

He has not placed upon you in the religion any difficulty (al-Qur'an, al-Haj 22:78)

يُريدُ اللهُ أنْ يُخَقِّنَ عَنَّْ

Meaning:

And Allah wants to lighten for you [your difficulties] (al-Qur'an, al-Nisa' 4: 28).

These two ayah proves that Allah in His Law does not seek to impose hardship and misery upon the people. Thus, whatever activities that would achieve the pleasure and convenience to the people, then it are allowed by Islam as long as it does not conflict with the maqasid al-shari'ah. Ibn Qayyim al-Jauziah views that shariah is essentially a rule of law that bring the benefit to the mankind in his life or the next life. The whole of the shariah is aims at bringing justice, love and wisdom and benefit to all (al-Zuhayli, 1986).

According to Kamali (2003), maslahah means 'benefit' or 'interest'. It is essentially an expression for the acquisition of benefit or the repulsion of harm. The acquisition of benefits and the repulsion of harm represent human goals, thus maslahah is achived when these goals are achieved through human welfare. Al-Raysuni (2006) views that maslahah is the preservation of the maqasid al-Shari'ah. That is the reason maslahah sometimes connotes the same meaning as maqasid, and scholars have used these two terms almost interchangeably.

Al-Imam al-Ghazali describes that the maslahah is an approach to celebrate the welfare of people and eliminate harm. It has a close relationship with maqasid al-shariah that covers five main elements to be preserved, which are religion, life, intellect, lineage and property. Anything that safeguards these five elements, then it is called maslahah. And whatever goes against their protection is mafsadah (al-Ghazali, 1997). Muhammad Rawwas Qala'hji (2000) has a same view with al-Ghazali and states that maslahah is an approach to promote the benefits and reject the evil.

Maslahah can be classified into three form, ie maslahah mu'tabarah, maslahah mulghah and maslahah mursalah (al-'Ummar, 2010). Despite the application of wa'd principle is not explicitly stated in the text or the consensus of scholars, but the application of this principle is in the category maslahah mursalah. According to al-Zuhayli (1998), maslahah mursalah is an attribute or statement in line with the action and purpose of Islamic law, but found no specific evidence from the text for its approval or disapproval. However, its implementation is included in the maqasid al-shari'ah as it would give maslahah to people and avoids harm. According to Mahmood Zuhdi (2012), maslahah mursalah should not be ignored completely. Though maslahah mursalah is not mentioned explicitly in the al-Quran, but if it does not contradict with definitive text, then the ruling which serves the genuine interest of people and harmony with the shariah should be enacted.

\section{The Clash between Maslahah and Mafsadah in the Application of Islamic Foreign Exchange Contract}

Some jurists are still debating about the permissibility of wa'dan principle to be adopted in structuring Islamic forward foreign exchange contract. Some of them argue that the adaptation of wa'dan principle will tend to permits structures that is mimicking conventional forex contract. While some jurists opine that the contract will bring maslahah since Islamic financial products will become innovative and competitive in providing a commercial value as well as comply with shariah requirements.

Due to no injunction and clear evidence that states the impermissibility of wa'dan and no clear evidence that allows it, thus it shows that it has a prospect to be explored in more depth. This is based on a famous fiqh maxim stated that: the norm in transaction is that of permissibility. The maxim shows that, in case the shariah is silent and where there is no legal text that either permits or prohibits it, the transaction is lawful. The application of 
wa'dan principle could reach maqasid al-shari'ah if it is applied in the right way without any manipulation. Although the use of wa'dan principle would bring some maslahah, we have to assured that it is the real maslahah and no implicit masfadah behind it. Therefore, this section will explore further about the issue of the clash between maslahah and mafsadah in the application of Islamic foreign exchange contract. Which one is more prevail, maslahah or mafsadah?

\section{a) Realization of Maslahah}

$W a^{\prime} d$ in Islamic finance is a principle that is flexible enough to create innovative products for hedging purposes. However, the issue that arises in the execution of binding $w a ' d$ is the failure to protect corporate clients when declining in exchange rate as compared to the rate agreed upon in the wa'd. The application of wa'd is Islamic foreign exchange forward does not only make the contract become shariah compliance, but the principle of wad is deemed to be more flexible and easy to apply. This means that, in addition to its shariah compliance, the application of the wa'd principle provides ease, does not involve complicated transactions and requires no additional cost compared to other shariah principles. Shariah's acceptance of the concept of $w a^{c} d$ is also not in its entirety as it only binds the one party. To overcome this weakness, the use of wa dan principle has been proposed (Alisa et al., 2012).

According to Shamsiah (2011), two unilateral promise (wa'dan) is the best principle to be adopted as wa'dan is tend to provide justice ('adalah) compared to the unilateral $w a$ ' $d$ in the current practice. Because both parties involved are bound by $w a^{\prime} d$ made, both of them will be protected and secured when there is no opportunity for the counter parties to default. Realisation of justice means maqasid al-shari'ah would also be achieved when all parties involved attain maslahah.

The nature of wa'dan which is very flexible makes it easy for Islamic banking to replicate conventional financial products such as derivatives in a shariah compliant manner (Alisa et al., 2011). To avoid harm (darar) of Islamic investors choosing the conventional forward FX products rather than Islamic products, hence a product which is similar to conventional forward FX contract is a requisite in Islamic banking and finance. Furthermore, the application of wa'dan principle is in fact a matter of ijtihadiyyah because it is new in the field of Islamic financial transaction. Although Islamic law is already complete and comprehensive, but some of its law is fixed and permanent, whereas some are flexible and changeable depends on the appropriate time and place. Therefore, an ijtihad is an important mechanism to realize the nature of flexibility and innovation behind the comprehensiveness nature of shariah (Rabiah, 2012). Siddiqi (2010) also urges that, the need of the hour is to encourage ijtihad based on shariah objectives to face the future challenges. This means that the principle of $w a$ 'dan has a wide potential to further develop hedging in Islamic financial institutions globally, particularly in Malaysia.

It is known that all market participants such as international trade as well as Islamic financial institutions are constantly exposed to foreign currency risk, particularly if the payment for the sale and purchase or lease is done by using different currencies. The currency exchange in the future can either give a profit or loss to one party or both parties, which are either buyer or seller or both. To avoid banking institution from the negative impact of price fluctuations and uncertainty, then Islamic FX forward contracts is needed for export and import industry to fulfil their hedging purposes. Without the applicability of this contract, then market participants will be exposed to losses that are darar for them (Alisa, 2012).

Islamic FX forward contracts based on wa'dan provide many benefits to the market players who are exposed to various types of risks. The contract is beneficial in terms of wealth protection under maqasid al-shari'ah as well as meeting the social needs of people. Preservation of wealth (hifz al-mal) is included in daruriyyat al-khamsah shows the significance of economic governance in Islam. Islamic banking institutions and corporations, investors and all market players would bear huge losses that will eventually dampen economic system as a whole if such hedging contracts of Islamic FX forward are not offered in the Islamic financial market.

Due to concerning of shariah to the easiness of the people, therefore any product development such as Islamic derivatives contract must be for the needs and to get rid of trouble and inconvenience to the people. So, the customer will benefit from a certainty at a price to be paid or cash flows to be received by him, thus giving flexibility in managing foreign currency position. The effectiveness of Islamic FX forward might bring more maslahah as long as in line with shariah.

The need to adopt the principle of wa'dan in Islamic FX forward contracts is considered as the common needs of the people (al-hajah al-'ammah) if it cannot be categorized in al-darurah al-shar'iyyah (extreme necessity, in which the Muslim cannot manage without). This is because the contract is essential for the purpose of protecting property which is one of essential needs in the maqasid al-shari'ah. 
Due to the usage of wa'dan is included in maslahah hajiyyah, then it is required as a convenience to the people and at the same time it is able to avoid trouble and difficulty. However, the absence of maslahah will not affect someone's life but will only cause some inconvenience (al-Shatibi, 1991). This is supported by the following maxims:

الحاجة تنزل منزلة الضرورة عامة كانت أو خاصة

Meaning:

Need is ranked as necessity, be it public or private (al-Suyuti, 1990).

الحاجة العامة تنزل منزلة الضرورة

Meaning:

Need is ranked as necessity (al-Suyuti, 1990).

The above fiqh maxims do not reflect that all maslahah practice will reach to the extreme necessity levels. This also does not mean that the concept of darurah can abandon maslahah mu'tabarah and mafsadah mu'tabarah or any Quranic texts. Rather, it means maslahah mursalah and darurah is part of maslahah shar'iyyah in general. For any maslahah mursalah is part of maslahah shar'iyyah, then darurah is also a part of maslahah shar'iyyah general (Ridzwan, 2004). Thus, Islamic FX forward contract is permitted based on the people's needs. If the need become general, then it will be considered as indispensability.

The need to adopt wa'dan principle in Islamic FX forward contracts for hedging purposes can be grouped in the category of maslahah mursalah. This is because the purpose of using wa'dan principle is merely for hedging purpose which is in line with maqasid al shariah. When the use of wa'dan seen as capable of giving the benefit of the people, then we should stick with it. Furthermore, in muamalat, people know better about their needs and maslahah (al-Tufi, 1964).

As was mentioned earlier, Islamic hedging products is growing at slower rate compared to conventional products. Insufficient Islamic hedging contracts may hinder the development of Islamic banking institutions. As a result, it can lead to infertile creativity of Islamic banking and finance practitioners whereas they should be more creative in order to compete with conventional counterparts. According to Engku Rabiah Adawiah (2008), Islamic hedging is among the most lagging behind compared to the products of other Islamic banking. As a sequence, it is important to increase innovation in Islamic hedging products, so as to gain investors' confidence in Islamic financial transaction.

Maslahah can also be achieved when the application of Islamic foreign currency forward based on wa'dan would ensure that Islamic banks continue to grow competitively with conventional banks. To promote Islamic economics as well as compete with the conventional economy, investors' confidence to participate in international trade is indispensable. To boost investor confidence in the context of risk management, not only cutting-edge products that are needed, but appropriate instruments in which does not conflict with shariah is a must. This is because the international trade transaction cannot be separated with foreign exchange activities. While foreign exchange transactions in reality are constantly exposed to various types of risk.

In addition, flexibility as well as dynamism of sharia has facilitated the development of new products and innovations in Islamic finance sector. The system is expected to compete with conventional financial system and recorded remarkable growth every year. From the maslahah perspective, wa'dan is more suitable and applicable to fulfil the current need of the market as it is an essential requirement for the development in Islamic financial market.

According to Ashraf Wajdi (2010), Islamic hedging products for the time being in fact still at its infancy stage. So far, Islamic hedging products introduced in Malaysia only focused on the management of foreign currency risk and interest rate risk. In fact, Ashraf Wajdi (2010) views that the nature of the market is too volatile, especially in the context of market interest rates and the currency. Therefore, the Islamic hedging products are required for this purpose. This is also suggests that the practice of currency exchange can be considered as one of the most important needs (al-daruriyyat). Therefore, the transaction is allowed by Islam to its people in their dealings.

Islamic FX forward contracts are also beneficial in terms of protecting the welfare of the society and minimizing the probability of business disruption. In the absence of innovation in Islamic FX forward contract, then the business or investments made by Muslim traders are vulnerable to loss due to risk management instruments is limited. Businesses or investments in Islamic finance sector will be less competitive when the diversity of the hedging instrument is limited to only a few products (Obiyathulla, 2004). Furthermore, Islamic financial system 
was built within the framework of the conventional financial system that was already well established and widely accepted in the community. Thus, the application of this wa'dan potentially increases competition between conventional and Islamic, and hence increases the growth of the Islamic financial system itself. Once the size of the assets of Islamic financial institutions increased gradually, so hopefully they can reduce dependency on the usage of wa'dan and find an alternative that is based on sharia (Islamic shariah based), rather than Sharia-compliant (shariah compliant).

Other maslahah that can be achieved in the application of wa'dan in developing hedging product is that, Islamic financial institutions would get a great opportunity to continue to expand the size of their business. At present, the total assets held by Islamic financial institutions only one per cent of the conventional (Akram, 2010). The small asset size has made the development of Islamic finance in a very challenging position. This is because the conventional dominate global financial markets where Islamic finance lags behind. Thus, although there is no clear text discusses about the potential application of wa'dan in Islamic FX forward contracts for hedging purposes, but custom practice ('urf tijari) can take place as permissible evidence.

International trade at present far more impressive and growing so fast. Thus, due to the current needs and changing times, then a robust innovation is required. This means, business custorm ('urf tijari) needs some reform of the contract such as Islamic FX forward contracts based on wa'dan to meet the hedging needs. In a fiqh maxim also mentioned:

لا ينكر تغير الأحكام بتغير الأزمان

Meaning:

Change of judgements shall not be denied by change of times (al-Zarqa', 1968)

Although Islamic law jurisprudence has been set, but some ruling may change if it is beneficial to mankind. In fact, the original purpose of the designation of Islamic law is to promote benefit of all people. The maslahah of mankind will always change and grow along with the progress of time. Thus, the above fiqh maxim shows that we have the freedom to innovate in structuring Islamic financial products in the event that it has become 'urf and give maslahah to mankind.

In essence, emphasize on the importance of global Islamic economy is maslahah 'ammah and will not affect the welfare of the individual which is maslahah khassah. This is because the individual maslahah is included in maslahah 'ammah through the mergers of mutual interest of individual within the society. Hence, if maslahah 'ammah is not the main concern, of course, the harm will befall on the individual, and the individual maslahah will be deprived. When maslahah 'ammah is the priority, then maslahah khassah would indirectly be protected as maslahah khassah included in maslahah 'ammah (al-Buti, 1982).

Islamic FX forward contracts based on wa'dan has made foreign exchange contracts shariah compliant because the issue of interest is no longer occur as per the existence of riba in the conventional forward FX contracts. By entering into Islamic FX forward contract, no interest occurs due to al-sarf contract has not happened yet, but the promise made in advance to do a foreign exchange contract in the future. Al-sarf contract only occur in the future whereby at that time the currency will be exchange on the spot basis. Thus, the issue of interest does not arise as promise made yet to form a sale contract.

The application of wa'dan Islamic FX forward contracts also give a maslahah because it gives a guarantee to customers when they make an appointment with the bank to sell or buy a specific amount of foreign currency fixed rate. Rates are determined based on the mutual agreed price even though the price of currency changes after that. If wa'dan is not allowed, then it will cause trouble (mashaqqah) to people. Whereas it can be considered as a lightness and grace of God that allows some rulings built based on maslahah. Thus, hedging is needed to protect them from harm thereby to safeguard the interests and rights of customers.

FX forward contracts based Islamic wa'dan is needed as it seeks to meet hajiyyah maslahah of people. The hajiyyah is more prominent when it involves a larger organization such as a large investment bank or multinational companies seeking to hedge. The principle of wa'dan also required to make a hedging product that is comparable to conventional. Makes the product more equivalent to conventional products is a strong reason to allow the economy to grow in line with economic conventional. The development of Islamic economics is an important maslahah in the country. Without the use of Islamic FX forward contracts for hedging, then corporates, Islamic financial institutions and Islamic economy will be in a position of greater harm. Thus, the usage of wa'dan in Islamic FX forward is in accordance with fiqh maxim which states that: A greater injury (harm) may be avoided by a lesser injury. Hedging product based on wa'dan is also needed based on shariah wisdom (hikmah tashri'iyyah), which gives maslahah to traders, investors and also to the economic system as a whole because it 
acts as a tool of risk management. The urgent need of this contract is required to ensure the survival of the Islamic banking institutions for the time being under the framework of the conventional financial system.

In line with the on-going evolution of modern society today, there are some new and innovative contracts are required in Islamic finance. Obiyathulla (1999) believe that, apart from looking at the point view of shariah, the advantages of derivatives should also be viewed in terms of social welfare. Due to the contemporary Muslim scholars do not agree with the use of derivatives, two negative effects will occur, namely: (1) the business or investments made by Muslims to be exposed to losses as risk management instruments are limited, (2) even business will become less competitive. Although the application of wa'dan in Islamic FX forward contracts is included in the category of makharij, but it is a form permissible hilah. This is because there are only few hedging contracts offered by Islamic financial institutions.

\section{b) Mafsadah}

Despite the benefits (as discussed in part a), permitting for the application of wa'dan in Islamic FX forward contract open a back door of speculation which the shariah did not intend to allow. Although Islamic FX forward contracts are essentially innovated for hedging purposes, nonetheless this instrument is also well-known for speculation purposes. Its mean that, the authorization to use the contract for hedging activities is also opens to speculators to speculate on price movements. Skilful speculators can gain huge profits by manipulating against the price volatility in the market, instead of hedging.

Speculation is a great harm (mafsadah) because it can result in market participants' loss. It is also led to injustice and instability in the financial world. While Islam has stipulated that currency cannot be traded since money is not a commodity. Furthermore, most of the world financial crisis that occurred in the past has a very close relationship with speculation. This large-scale speculative activity can result in economic instability and economic collapse (Obaidullah, 2005). This scenario demonstrates that while Islamic FX forward contract has a big role in hedging activities, but the same contract can also be easily manipulated by speculators.

Although Islamic FX forward contracts based on wa'dan allow market players not to involve in usury transaction, but, in fact, Islamic financial institution has done the same thing with conventional financial institutions indirectly because the resulting effect is the same. It is merely a hilah to circumvent riba which is prohibited in Islam. Moreover, currency trading is easily manipulated for gaining huge profit, rather than to hedge. Traders who open a position (either buy or sell) do not know that when the contract was made, how much the price of the currency to be received during the close position.

For example, when an open a position to buy (long) EUR/USD at 1.4573, A does not know the exact amount until he take a close position to resell the EUR/USD to the broker. The difference between the open and close price will be credited to account A if there is a rise in the currency EUR/USD. However, if the currency rate decreases, then the price difference is debited from account A and credited to the broker's account (Marjan et al., 2011). This activity can result in only one party bearing loss while the other party earning profits. Based on these characteristics, the contract is seen to have speculating features.

\section{Discussion and Finding}

Based on the above arguments, there is, in fact a clash between maslahah and mafsadah in the implementation of Islamic FX forward contract based on wa'dan. Sometimes people assume that the contract will bring maslahah and achieve maqasid al-shari'ah, instead there may be mafsadah otherwise. If the usage of wa'dan in Islamic FX forward contract is not permitted, not only maslahah cannot be achieved, rather it will bring into mafsadah. This is due to limited number of hedging products for Islamic investors and this factor encourages them to choose conventional products, which is not Shariah-compliant. Therefore, careful consideration should be made between obtaining maslahah and rejecting mafasid.

It is recognized that maslahah Muslims in economic activities is very important, but greater harm should be removed. A real achievement of maslahah is not solely taking into account when the maslahah can be achieved, rather it is largely depends on mafsadah aspects that could be rejected (Ridzwan, 2004). 'Abd Ibn al-Salam (t.th.) states that the purpose (maqsad) is more important than means (wasilah). This means, the purpose of hedging should be given priority over the means. Nevertheless, it does not mean that the means can be ignored totally since the means is an important element that can lead to the achievement of maqsad.

As a result of the high chances of mafsadah in the use of Islamic FX forward, then the application of Islamic FX forward contract based on wa'dan should be allowed only on the basis of necessity (hajah) only. The application of this contract is limited to hedging activities only and this contract does not open for any other activities such as speculation. The currency cannot be traded in any way since money is not commodity trading. Thus, there 
should be some restrictions on the application of Islamic FX forward based on wa'dan. If the currency is traded, then the mafsadah will be worse off and it will greater than maslahah as the activity can collapse the economy.

The following fiqh maxim shows that rejecting unlawful activities are more vital in Islam.

جواز ارتكاب أخف الضررين

Meaning:

The lesser of two harm is to be committed (Hazm, 1996).

When permissible activities such as wa'dan in Islamic FX forward are applied, then it is deemed to have celebrated the betterment and maslahah of mankind. However, when it is used to eliminate maslahah, then it will invalidate the original ruling outlined by shariah. The process of identifying the compliancy of financial instrument in the Islamic law requires the ability of scholars to understand the instrument in terms of concept and execution. This is consistent with the maxim below:

ا كم على شىء فرع عن تصوره

Meaning:

The decided ruling is depending on the understanding (al-Mardawi t.th.).

According 'Abd Ibn al-Salam (1998), the degree of maslahah and mafsadah in the eyes of Allah SWT is measured by the extent to which some act can produce maslahah or avoid mafsadah. When a contradiction occurs between maslahah and mafsadah, then the most dominant between them will be given priority. Therefore, in this context, although there is mafsadah when Islamic FX forward contracts is misused for speculation, but the use of this contract can be put into some restrictions. If this contract is restricted in term of its practice is, then speculation can be minimized. This means that, when hedging activities are more dominant than speculation, then maslahah from the use of these contracts for hedging purposes is greater than the possibility of the occurrence of mafsadah. This assertion is supported by al-Qarafi (2001) which states that, in some activities, if the maslahah is larger and dominant than mafsadah, then the activity can be taken into account.

The determination of whether Islamic FX forward contracts based on wa'dan is needed or not is depending on the benefits achieved from the implementation. According to Ibn al-Hajib (1985), rejecting mafsadah is getting priority over getting maslahah just as a matter of precaution, so that the decisions made is in compliance with Islamic law and human reasoning. However, Ibn Taymiyyah (1994) views that; a contract may not be illegal as long as there is no Islamic law says so.

al-Qaradawi (2001) states that the overall shariah ruling is built based on the method of facilitates (taysir) and not too riqid. The ruling should not be based on grief ( $u s r$ ) whereby there is no way out to the need of mukalaf. This is amplified by the method of jurisprudence follows:

$$
\text { أولوية التخفيف والتيسير على التثديد والتعسير }
$$

Meaning:

Choosing ease dan flexible is prior to rigid dan hardship (al-Nadawi, 1999).

Based on that, facilitates (taysir) approach is needed and it is used widely by the mujtahid jurists. This means that the mujtahid is not to be bound by strict laws because it is not a requirement by the fundamental law. This approach is also needed to meet the needs and facilitate the structuring aspect of hedging products in order to meet the needs of the market as a whole.

Finding a right balance between mafsadah and maslahah is a big challenge that should be addressed wisely. It is vital so that the decision of law does not lead to any constriction to the Muslims and no harm as a result of the relaxation of the law. Wa'dan parameter or standard should be followed so that its intended use does not contradict shariah guidelines. To get a clearer picture of whether maslahah or mafsadah is more prevailing in the application of Islamic FX forward based on wa'dan, the figure bellows summarize this discussion. Although the contract brings maslahah to all parties involved, the use of wa'dan without restriction and proper guidelines could lead to harm to the economy. Thus, the concept of compatibility in al-Quran with the concept maslahah and mafsadah must be continuously observed. So that the claimed maslahah is the real benefit while the rejected mafsadah is the real harm as specified in the maqasid al-shari'ah (Ahmad, 2004).

The following figure potrait that the application of the wa'dan principle gives maslahah to all parties, including investors, financial institutions, corporations and the economy. Nevertheless, the application of the wa'dan in Islamic FX forward also contains mafsadah if its usage is misused by speculators to manipulate the currency movement in a volatile market. 


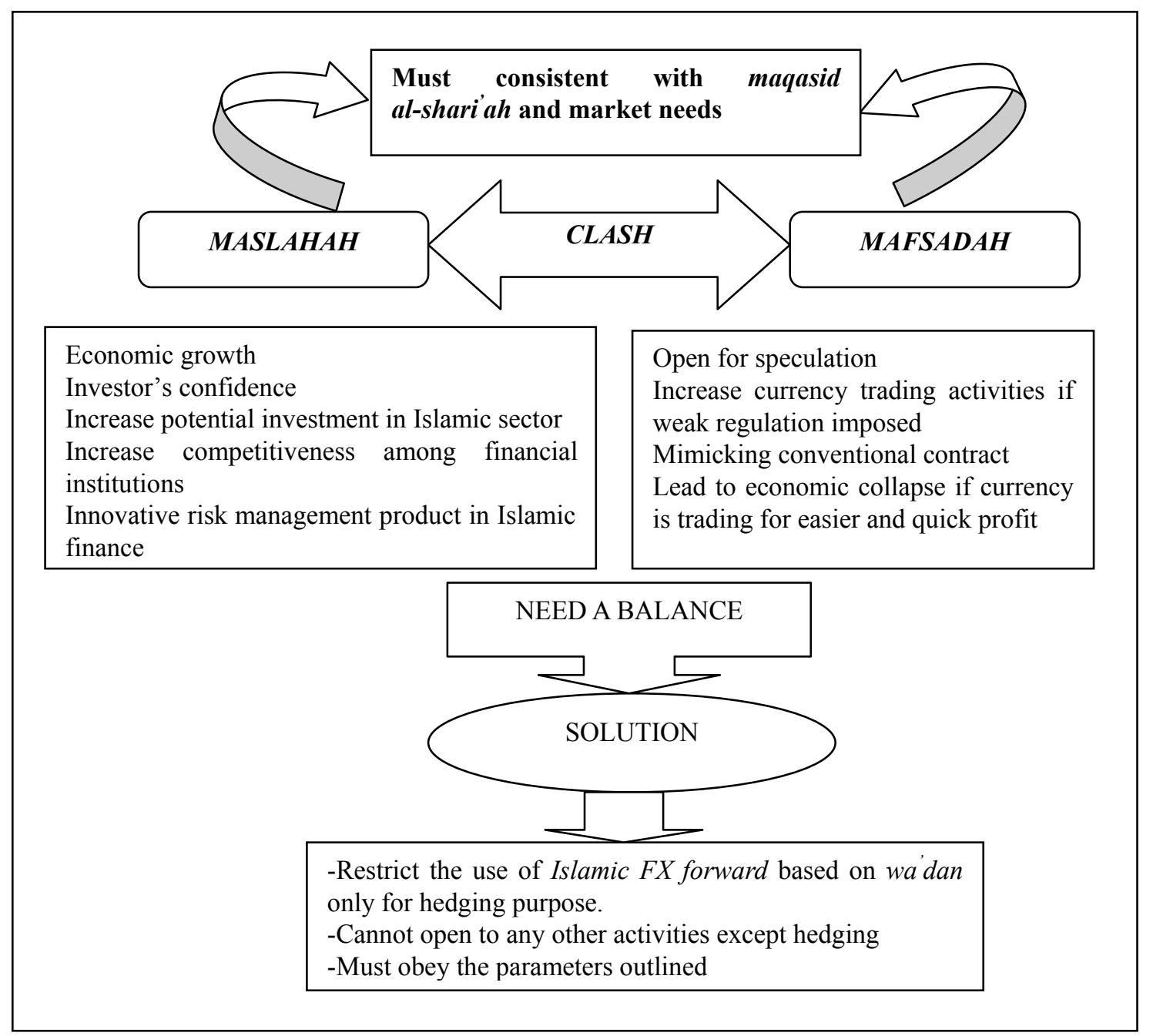

Figure 2. Analysing the application of wa'dan in Islamic FX forward contract

\section{Conclusion}

This paper concludes that Islamic FX forward contracts based on wa'dan capable of achieving maqasid al-shari'ah because it gives benefit to all parties. With the adoption of wa'dan principle, the ability of Islamic financial institutions in the diversification of Islamic hedging product can be improved. Based on the above discussion, it is clear that the principle of wa'dan is significant as it can be applied in structuring sophisticated Islamic hedging products and gives maslahah to the people and economy at large.

$W a$ 'dan is seen to have a tremendous potential to develop a competitive and innovative Islamic hedging products. It has also become a suitable alternative for Islamic financial products to compete with conventional financial products due to its flexible nature. While its implementation may present some difficulty in terms of documentation or simply increase quantity of documents available, but the use of wa'dan has a great potential to be applied in Islamic hedging products to enhance the competitiveness of Islamic banking products are essentially different from conventional banking products. If the application and process of Islamic hedging are transparent, thus the number of transactions in the market will increase, consequently it leads to the increase competition in the market. Wa'dan principle which is easily structured in Islamic hedging contract can also increase the innovation of hedging product; subsequently will boost the ability of Islamic financial institutions in the area of risk management. Therefore there is need for Islamic financial products to be innovative and growing from day to day. Hence, a collective ijtihad interpretation on the basic principles underlying Islamic hedging transactions is necessary to facilitate not only their compliance with the shariah, but also helps Islamic financial institutions to use the new products in the light of Islamic principles. 


\section{References}

Abdullah, N. I. (2008). The status of promise (wa'd) and its implications in contemporary Islamic banking.

Accounting and Auditing Organisation for Islamic Financial Institutions (AAOIFI). (2010). Accounting, Auditing and Governance Standards for Islamic Financial Institutions. Bahrain: Manama.

Ahmad, A. A. (2014). The Concept of Hedging in Islamic Financial Transactions. Asian Social Science, 10(8), 42-49.

Ahmad, A. A., Ahmad, S., Tahir, H. M., Shahimi, S., Mohamad, S., \& Zain, M. M. M. (2012). Islamic forward exchange contracts as a hedging mechanism: An analysis of wa'd principle. International Business Management, 6(1), 47-54. http://dx.doi.org/10.3923/ibm.2012.47.54

Ahmad, A. A., Mohamad, S., \& Shahimi, S. (2011). Innovative Islamic hedging products: Application of wa'd in Malaysian banks. Capital Markets Review, 19(1\&2), 33-52.

Ahmad, R. (2004). Standard Maslahah dan Mafsadah dalam Penentuan Hukum Islam Semasa di Malaysia. PhD. thesis, Jabatan Fiqh dan Usul. Akademi Pengajian Islam, Universiti Malaya.

Akram, M. (2010). Understanding the concepts of maslahah and its parameters when used in financial transactions. ISRA International Journal of Islamic Finance, 2(1), 61-84.

al-Buti, M. S. R. (1982). Dawabit al-Maslahah fi al-Shari ah al-Islamiyyah. Beirut: Muassasah Risalah.

al-Fayyumi, A. I. M. (2008). al-Misbah al-Munir. al-Qahirah: Mu'assasah al-Mukhtar.

al-Ghazali, A. H. M. B. M. M. A. T. (1997). al-Mustasfa min al-I'lmi al-Usul. Beirut: Muassasah al-Risalah.

al-Hajib, I., \& Jamal al-Din Abi 'Amru 'Uthman bin Amru bin Abi Bakr bin Yunus. (1985). Muntaha al-Wusul wa al-Jadal. Cetakan pertama. Beirut: Dar al-Kutub al-'Ilmiyyah.

Ali, E. R. A. E. (2012). Inovasi dan fleksibiliti dalam kewangan Islam semasa. Kertas kerja Muzakarah Penasihat Syariah Kewangan Islam 2012 Kali ke 7. Kuala Lumpur Islamic Finance Forum ke 9. Organized by Centre for Research and Training, Kuala Lumpur, 15 Oktober.

al-Mardawi. T.th. al-Insaf fi Ma rifah al-Rajih min al-Khilaf. Muhammad al-Faqi (pnyt.). Beirut: Mu'assasah al-Turath al- ${ }^{\mathrm{c}}$ Arabi.

al-Qaradawi, Y. (2001). Taysir al-Fiqh li al-Muslim al-Mu’asir. Beirtu: Muassasah al-Risalah.

Al-Quran

al-Raysuni, A. (2006). Imam al-Shatibi's: Theory of the Higher Objectives and Intents of Islamic Law. Kuala Lumpur: The International Institute of Islamic Thought.

al-Suyuti, J. A. D. 'A. A. R. (1990). al-Ashbah Wa al-Naza'ir Fi Qawa'id wa Furu' Fiqh al-Shaf'iyyah. Beirut: Darul Kutub al-'Ilmiyyah.

al-Tufi, S. I. ${ }^{\mathrm{C}}$ A. A. Q. (1964). Sharh al-Arbacin al-Nawawiyyah. Dlm. Mustafa Zaid. al-Maslahah fi al-Tashri al-Islami wa Najm al-Din al-Tufi.al-Qahirah: Dar al-Ra ${ }^{\mathrm{c}} \mathrm{id}$.

al-'Ummar, A. A. B. A. B. A. A. (1431/2010). al-Masalih al-Mursalah wa Atharuha fi al-Mu'amalat. UAE: Dar Kanuz Isybiliya li al-Nasyr wa al- Tauzi'.

al-Zarqa', A. I. M. (1968). al-Madkhal al-Fiqh al-'Am, (1\&2). Damshiq: Matabic Alif Ba' al-Adib.

Al-Zuhayli, W. (1986). Usul al-Fiqh al-Islami. Beirut: Dar al-Fikr.

Bacha, O. I. (1999). Derivatives instruments and Islamic finance: Some thoughts for reconsideration. MPRA Paper 12752, University Library of Munich, Germany. International Journal for Islamic Financial Services, 1(1). Retrieved March 13, 2010, from http://mpra.ub.uni-muenchen.de/12752/

Bacha, O. I. (2004). Value preservation through risk management-a shariah compliant proposal for equity risk management. MPRA Research Paper 12632. Germany: University Library \& Munich. Retrieved August 6, 2010, from http://ideas.repec.org/p/pra/mprapa/12632.html

Bank Negara Malaysia. (2010). Resolusi Syariah dalam Kewangan Islam. Edisi ke-2. Kuala Lumpur: Bank Negara Malaysia.

Billah, M. M. (2007). Applied Takaful and Modern Insurance: Law and Practice (3rd ed.). Sweet \& Maxwell Asia.

Daghi, Q., \& Ali, M. (2002). Buhuth fi al-Iqtisod al-Islami. Beirut: Darul Bashar al-Islamiyyah. 
Dusuki, A. W. (2010). Islamic perspectives on Islamic FX forward. New Horizon. Retrieved March 31, 2010, from http://www.newhorizonislamicbanking.com/index.cfm?section=academicarticles\&action

Hajar, I., \& Ali, A. I. (1993). Fath al-Bari bi Sharh Sahih. Al-Bukhari. Beirut: Dar al-Fikr.

Hasan, A. (2008). Pengertian al-wa'ad, al-wa'dan dan al-muwa'adah. Paper presented in Muzakarah Cendekiawan Syariah Nusantara 2008, Organized by International Shariah Research Academy for Islamic Finance (ISRA). 27-28 February.

Hazm, I., \& al-Zahiri, A. I. A. (1996). al-Muhalla, (7, 8 \& 11). Beirut: Dar al-Kutub al-Jil.

Ibn 'Abd al-Salam, Abu Muhammad 'Izz al-Din 'Abd al-Aziz bin 'Abd al-Salam al-Sulami. (1998, M/1418H). Shajarat al-Ma'arif wa al-Ahwal wa Salih al-Aqwal wa al-A'mal. Iyad Khalid al-Tabbba' (Pnyt.). Dimashq: Dar al-Fikr.

Kamali, M. H. (1989). Principles of Islamic Jurisprudence. Petaling Jaya: Pelanduk Publications.

Majid, M. Z. A. (2012). Maqasid al-Syari ah: Satu Pengenalan. In M. W. Mahmud, \& A. A. Aziz (Eds.), Maqasid al-Syaric ah (pp. 1-49). Selangor: Penerbit UIAM.

Mohamad, S., \& Muhamad, R. (2010). Produk perbendaharaan Islam: Isu syariah. Kertas kerja yang Muzakarah Penasihat Syariah Kewangan Islam 2010 (KLIFF 2010). Kali ke 5 di Hotel Nikko, Kuala Lumpur. 2-5 Ogos.

Nadawi, A. A. (1994). al-Qawac id al-Fiqhiyyah. Damsyik: Dar-Qalam.

Qal'ahji, M. R. (1421/2000). al-Mausu'ah al-Fiqhiyyah al-Muyassarah. Beirut: Dar al-Nafais.

Siddiqi, M. N. (2010). Maqasid-e Shari at (Objectives of the Shariah). J.KAU: Islamic Econ., 23(2), 235-244.

\section{Copyrights}

Copyright for this article is retained by the author(s), with first publication rights granted to the journal.

This is an open-access article distributed under the terms and conditions of the Creative Commons Attribution license (http://creativecommons.org/licenses/by/3.0/). 